\title{
Investments Information Via the Web by Malaysian Listed Companies
}

\author{
Azrul Abdullah*, Rosiatimah Mohd Isa* and Norshamshina Mat Isa** \\ *Accounting Research Institute and Faculty of Accountancy, UiTM Perlis, Arau, Malaysia \\ **Faculty of Business Management (Finance), UiTM Perlis, Arau, Malaysia
}

\begin{abstract}
Internet technology is believed to improve efficiency and good practice of information dissemination. This paper examined the investment information disclosed by Malaysian Listed Companies via their websites. Evaluations of investment informations disclosure via the websites were based on score towards the disclosure index developed. One hundred companies listed on the Bursa Malaysia's Mainboard are selected based on their market capitalization. This study identifies the level of investment information disclosure across industry and found that the investment information disclosure and usage of the multimedia are still unsatisfactory. This study also tests the extent of such disclosure with several firm characteristics (profitability, auditor, efficiency and size) and the result shows that only firm's size is significant. The implications of these findings are discussed.
\end{abstract}

Keywords: Investment disclosure, Malaysia

\section{INTRODUCTION}

In today's scenario where the emerging of internet technology, many companies tend to disclose investment information via their websites as one of the medium for business communications (see Lymer 1999, 2000; Hedlin 1999; Brenan and Kelly 2000), since the conventional glossy corporate report is a long-awaited demise. As reported by many international studies, investment information disclosure on internet able to serve as one of element to improve efficiency and good practice of information dissemination as well convey greater degree of transparency to its activities. This will then drive the formation and accumulation of reputation of the corporation of its future performance (i.e. Gowthorpe and Flynn 1997; Niamh, 1998; Maines, Bartov, Fairfield and Hirst, 2002). Lev (1992), furthermore, proposed that such ongoing investment information to shareholders on the company's activities via the internet capable to minimize uncertainty among investors as well minimizing the negative impacts on share prices. According to Ismail (2002), internet also can be comprehensive tool for investor relation activities because it is capable to ensure instant and voluminous availability of information at low cost as well as facilitating much broader and easier dissemination of information.
Although internet could provide much benefit to investors and other stakeholders, internet disclosure is yet a nonmandatory and unregulated. Companies are free to present and control the amount and type of investment data according to their own preferences. Therefore, there are many variations on the types, contents, presentations, and retrieval/ files formats through their corporate web sites. Due to this matter, it is believed that investors may be misled by such variation of contents and formats of investment information disclosed and later will make a wrong judgment and perception about the companies. In addition, such investment disclosure will create difficulties and time-consuming for investors to search for their desired information. Therefore, the effectiveness of investment information sections in today's companies' websites is questionable.

Previous international studies such as Brennan and Kelly (2000); Deller, Stubenrath and Weber (1999); Hedlin (1999), claimed that internet to be relatively cheap and extremely fast in presenting of useful information in various formats to the millions of people who use the internet every day. However, such investment information disclosures on the internet only practiced by several corporate sectors in developed countries. In Malaysia, number of studies (i.e. Ruhaya, Nafisah and Normahiran, 2000; Noor and Mohamad, 2000; Abdul Hamid, 2005; Abdul Hamid, 2005 and Khadaroo, 2005), reported that the extent of investment disclosure by Malaysian companies was not well utilized the full potential of investment disclosures due to non existence enforcement of specific guidelines. Companies were merely disclosed what they intended to disclose.

Based on such reported research findings, accounting regulatory bodies of various countries, including Malaysia, have taken initiatives to help and encourage companies to utilize and make use of electronic media in providing useful information to their stakeholders. Thus, a question agitated the mind of researchers, "Are Malaysian companies making optimal use of the internet as a method of disseminating and disclosing investment information to investor in today reporting environment?" This study attempts to answer the questions and highlight its findings. For a more accurate 
insight, the level of web based investments information disclosed are examined in two essential aspects: (i) contents and (ii) forms of information presentation. This study also aims to discover the variables that have significant influence on the level of investment information disclosure via the websites.

\section{LITERATURE REVIEW}

Moving to electronic age, where internet becomes a favoured medium, an electronic disclosure of business information may serve several advantages to company stakeholders. If business information disclosed electronically, this might beneficial to the company since may help to reduce their production cost associate in delivering business information, enhance their valued added capabilities, effectively manage the supply of financial and non financial data and capable to reach a broader information's audience (see Louwers, Pasewark, William and Eric, 1997; Deller et al., 1999; Maines et al., 2002; Marston, 2003). According to Shelly and Vermaat (2009), a useful and high value of a Web site should meet their proposed criteria. They stated that, in evaluating the usefulness and the value of a web site, one could rely on: (i) Affiliation; the company should support the web site without bias in the information, (ii) Audience; the Web site should be written at an appropriate level, (iii) Authority; the Web site should list the author and the appropriate credentials, (iv) Content; the Web site should be well organized and the links should work, (v) Currency; the information on the Web page should be current, (vi) Design; the pages on the Web site should download quickly and be visually pleasing and easy to navigate, (vii) Objectivity; the Web site should contain little advertising and be free of preconceptions. As the company's information usually used to analyze the company's performance and ability particularly by existing and future investors, and realizing that the investment information via the internet is capable to offer such advantages to the investor community, a substantial number of studies provide evidence on usefulness of internet in disseminating and enhancing communication in terms of production and distribution costs associated (See Marston, 1996; Louwers et al., 1999; Connor, 2000; Khadaroo, 2005). It was claimed that, the more investors agreed to receive information electronically, the greater the potential savings would be for companies. In addition, there is several studies extent the evidence relating to investment information on the internet. These studies particularly focus on search ability and presentation capabilities of investment information that allow companies to disseminate well about their business information (see Hedlin 1999; Marston, 2003; Abdul Hamid 2005).

Even though disclosure of investment information via the companies' websites is useful for companies and investor community, the information normally disclose voluntarily (see Ashbaugh 1999; Craven and Marston, 1999; Ettredge, Vernon and Susan 2002; Kerchoven 2002; Khadaroo 2005). International studies revealed that many companies do not fully utilise their websites. One of the earlier studies conducted by Petravick and Gillet (1996) claimed that only
69 percent companies in USA had websites and 54 percent had some form or investment information on their site. Similar study done Deller et al. (1999) reported that 91 percent USA's S\&P 500 corporation were using the web for investor relation. In 1997 further study had been conducted in UK and Finland by Lymer and Tallberg. They claimed that companies based in UK and Finland limit their investment disclosure towards their business reporting in the websites. In another study conducted by Marston (2003) highlighted that only 68 Japanese companies were showing financial information and 57 providing detailed accounting information. The study stated that company size was not related to extent of the information disclosed but significantly related to the existence of the website. Similarly, Craven and Martson (1999) also reported the same finding in the study conducted in UK.

Although there have been considerable effort to measure the extent of companies' reporting via their websites, only a handful of them particularly addressed the issue of investment disclosure (see Marston, 1996; Hedlin 1999; Deller et al. 1999; Brennan and Kelly 2000: Ettredge et al. 2002; Maines, et al., 2002). In the USA, Louwer et al. (1996) revealed that most investment informations in the websites only cover the financial information. This financial information simply duplicates the hard copy or portion of the hard copy in hypertext form. In their study, they also found that most companies emphasize on other business information such as product and marketing information. However this information is hidden under the topics of corporate overview, stockholders informations and financial informations. This indicates that not much effort was made by firms to explain investment information in the websites. In another study, Hussey, Gulliford, and Lymer (1998) claimed that only leading companies have high tendencies to disclose financial information. The study showed that the investment information takes a number of different forms and mostly the summarization of the conventional published financial statement. Further investigation on investment disclosure also reported in 1999 by Hedlin which study on Swedish firms. The study found various investments information disclosed by the firms. Eighty three (83) percent of the firms had a financial report on the web and 12 percent had a hyperlink for the interpretation of financial report. In 2002 similar study also been conducted on the Irish companies by Brennan and Kelly. The study revealed that the investment information presented in $84 \%$ of the companies via their website.

In Malaysia, research on investment information disclosures is still at the establishment stage. Few studies were found with regard the disclosure of investment information in the company's website (i.e. Ruhaya, Nafisah and Normahiran 2000; Noor and Mohamad 2000; Nik and Amdan 2001; Salleh, Nariah Mazlin and Shireejit 2002). These studies gave descriptions on the trend of internet reporting in Malaysia. Extended study conducted by Khadaroo (2005) showed that there still a variation in the extent of internet information reporting practices of Malaysian listed companies as compared to Singapore. 
Companies in Singapore have a greater web presence compared to Malaysia. Investment informations was reported not well presented to the investor in the company's web by Malaysian companies. Meanwhile Abdul Hamid (2005) further highlighted that Malaysian companies were not utilized the full potential of the internet as they are more rely on traditional way of investor relation. The study highlighted that 93 percent companies provided company background in their websites, 50 percent showed historical press release, 45 percent showed current annual report and 31 percent for EPS. The study presumed that company size could be one of the factors of such disclosure hence further investigation on motivational factors for disclosure is suggested. The motivation for the disclosure can be explained by various theories (see Singhvi and Desai, 1971; Watts and Zimmerman 1978; Raffournier, 1995; Inchausti, 1997; Botosan, 1997; Ahmed and Courtis, 1999) such like signalling theory. The theory predicts that companies disclose information via their websites to signal their reporting quality, then it would be expected that certain company attributes would be associated with investment disclosure. Hence, this study used this theory to explain the relationship between the extent of investment disclosure and selected firm characteristics.

\section{DATA AND METHODOLOGY}

\section{A. Sampling and Data Collection}

A sample of 100 companies was selected from the list of top companies in 2008 (according to market capitalization). The sample size is assumed sufficient as it satisfies the rule of thumb proposed by Roscoe (1975) who suggested that a sample size larger than 30 and less than 500 is appropriate for most researches. Following this rule of thumb, many researchers concluded their study based on different number of sample size. For example, Lymer (1999) who studied the adequacy of Internet Financial reporting in UK only employed 50 top companies. Subsequently, Marston (2003) in examining internet financial reporting by leading Japanese companies used only 99 top Japanese companies.

\section{B. Investment Disclosure Index, Explanatory Variables and Model}

To construct the investment disclosure index (IVDi), this study began by monitoring Malaysian listed companies websites for a year. Later, a checklist of instrument was then developed. Supported by previous studies on disclosure (e.g.Wallace, Naser and Mora 1994; Wallace and Naser, 1995) which stated that there was no theory on the number and selection of items to be included in the disclosure index, hence, this study classified investment information disclosure into 3 themes (i.e. Strategic Information, Financial Information and Non Financial Information) that contains 12 categories of item. Then, a score sheet was prepared to determine the number of business information reported in the website of the sample firms. A score of 1 is given for each item disclosed and 0 for each item not disclosed by each company. A disclosure index was then calculated in which the total number of investment information reporting is divided by the maximum score. This scoring method also known as unweighted approach, based on the assumption that each item of disclosure is equally important.

An ordinary least square (OLS) regression test was conducted in order to test the investment disclosure and selected firm characteristics( PROFITABLITY-measure by using operating profit margin; AUDIT FIRM - a dummy variable of 1 if company is audited by one of big four auditing firms and 0 if otherwise; EFFICENCY- efficency of the company, measured by \% change in sales from the previous year; SIZE- size of the company, measured by the natural $\log$ of market capitalization. In order to reduce the errors of the distribution and the potential effect of the size of the variables on the regression equation, the market capitalization was transferred into its natural log (see Ahmed and Nicholls 1994; Wallace and Nasser 1995). The model is represented by the following equation:

$\mathrm{IVD}_{i}=\alpha_{0}+\beta_{1}$ PRO $+\beta_{3} \mathrm{AUDI}+\beta_{4} \mathrm{EFFIC}+\beta_{5} \mathrm{SIZE}+\varepsilon(1)$

\section{FINDINGS AND DISCUSSIONS}

\section{A. Descriptive Results}

From the study of 100 Malaysian listed companies, only 95 companies (95\%) were found to have their own websites. As compared to previous study on the internet disclosures such as by Abdul Hamid (2005), and Khadaroo (2005), this study reported an increment in the number of companies that own web site, approximately by 20 percent. This increment might be due to the different period of the studies and enhancement of the company awareness (see Abdul Hamid, 2005; Khadaroo, 2005). For investment disclosure on the company's websites, this study reduces the sample size to 95 companies due to the non-existence of websites of the five companies. The five companies were from manufacturing, trading/services, and others sectors.

TABLE I. Multimedia AND PRESENTATION Format OF INVESTMENTS INFORMATION

\begin{tabular}{|c|c|c|c|c|}
\hline TYPES OF INDUSTRY & 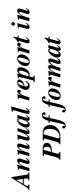 & 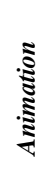 & $\underset{\Sigma}{\mathbb{2}}$ & $\stackrel{8}{\mathbb{5}}$ \\
\hline Manufacturing & 11 & 10 & 2 & 3 \\
\hline Property & 10 & 14 & 0 & 2 \\
\hline Construction & 20 & 0 & 0 & 0 \\
\hline Plantation & 16 & 8 & 0 & 0 \\
\hline Trading and Services/ others & 12 & 8 & 4 & 0 \\
\hline TOTAL & 69 & 40 & 6 & 5 \\
\hline
\end{tabular}

Connor O'Kelly (2000) highlighted that one of the user demands that drive reporting to online media was due to richness in terms of new media, graphic, rich contents and multimedia capabilities. In terms of multimedia and presentation format of disclosure, we found that only 40 companies adopt animation in their website (Table I). The 
highest number of disclosure was from property industry (14 companies), followed by manufacturing (10 companies), plantation ( 8 companies), and trading and services/others ( 8 companies). No animation presentation format was found in construction sector. Audio presentation seems to be the least popular among the Malaysian companies as only five companies were reported (i.e. three from manufacturing industry and the remaining by property industry). In this study, we found that none of the companies adopts XBRL (Extensible Business Reporting Language) for financial reporting format during the period of study. Annual report in PDF format is another form of disclosure via company website. It was found that 69 companies disclose annual report (at least 1 year) in this format. The industry breakdown in Table I reveals that construction sector disclose the highest (20 companies) while property sector is the lowest.

TABLE II. DISTRIBUTION OF INVESTMENT INFORMATION ON MALAYSIAN LISTED COMPANIES' WEBSITE BY INDUSTRY

\begin{tabular}{|c|c|c|c|c|c|c|c|c|c|c|c|}
\hline \multirow{3}{*}{$\begin{array}{c}\text { Investment } \\
\mathbf{s} \\
\text { Informatio } \\
\mathrm{n}\end{array}$} & \multicolumn{10}{|c|}{ TYPES OF INDUSTRY } & \multirow{3}{*}{$\begin{array}{c}\text { TOTAL } \\
\text { No } \\
\end{array}$} \\
\hline & \multicolumn{2}{|c|}{ Manufacturing } & \multicolumn{2}{|c|}{ Property } & \multicolumn{2}{|c|}{$\begin{array}{c}\text { Constructio } \\
n\end{array}$} & \multicolumn{2}{|c|}{ Plantation } & \multicolumn{2}{|c|}{$\begin{array}{c}\text { Trading } \\
\text { services \& } \\
\text { other }\end{array}$} & \\
\hline & No & $\%$ & No & $\%$ & No & $\%$ & No & $\%$ & No & $\%$ & \\
\hline \multicolumn{12}{|c|}{ Strategic Information } \\
\hline \begin{tabular}{|l|} 
Corporate \\
Information
\end{tabular} & 14 & 15.73 & 18 & 20.22 & 20 & 22.47 & 20 & 22.47 & 17 & 19.10 & 89 \\
\hline \begin{tabular}{|l|} 
Corporate \\
Strategy \\
\end{tabular} & 8 & 17.78 & 4 & 8.89 & 15 & 33.33 & 8 & 17.78 & 10 & 22.22 & 45 \\
\hline \begin{tabular}{|l|} 
Research \& \\
Developme \\
nt
\end{tabular} & 4 & 22.22 & 0 & - & 0 & - & 12 & 66.67 & 2 & 11.11 & 18 \\
\hline \begin{tabular}{|l|} 
Future \\
Prospect
\end{tabular} & 5 & 13.16 & 8 & 21.05 & 10 & 26.32 & 12 & 31.58 & 3 & 7.89 & 38 \\
\hline \begin{tabular}{|l|}
$\begin{array}{l}\text { Sustainabili } \\
\text { ty }\end{array}$ \\
\end{tabular} & 14 & 15.73 & 18 & 20.22 & 20 & 22.47 & 20 & 22.47 & 17 & 19.10 & 89 \\
\hline \multicolumn{12}{|c|}{ Financial Information } \\
\hline $\begin{array}{l}\text { Annual } \\
\text { report }\end{array}$ & 11 & 15.94 & 10 & 14.49 & 20 & 28.99 & 16 & 23.19 & 12 & 17.39 & 69 \\
\hline \begin{tabular}{|l|}
$\begin{array}{l}\text { Quarterly } \\
\text { report }\end{array}$ \\
\end{tabular} & 3 & 15.00 & 3 & 15.00 & 7 & 35.00 & 5 & 25.00 & 2 & 10.00 & 20 \\
\hline $\begin{array}{l}\text { Financial } \\
\text { highlight/R } \\
\text { atio } \\
\text { Analysis } \\
\end{array}$ & 4 & 16.00 & 2 & 8.00 & 8 & 32.00 & 8 & 32.00 & 3 & 12.00 & 25 \\
\hline \begin{tabular}{|l|} 
Share price \\
Information
\end{tabular} & 8 & 15.09 & 8 & 15.09 & 15 & 28.30 & 16 & 30.19 & 6 & 11.32 & 53 \\
\hline \multicolumn{12}{|c|}{ Non Financial Information } \\
\hline \begin{tabular}{|l|} 
Director \\
Information
\end{tabular} & 10 & 14.08 & 12 & 16.90 & 20 & 28.17 & 16 & 22.54 & 13 & 18.31 & 71 \\
\hline \begin{tabular}{|l|} 
Social \\
Policy and \\
Valued \\
added Info \\
\end{tabular} & 13 & 16.67 & 10 & 12.82 & 20 & 25.64 & 20 & 25.64 & 15 & 19.23 & 78 \\
\hline \begin{tabular}{|l|} 
Employees \\
Information
\end{tabular} & 7 & 20.59 & 2 & 5.88 & 10 & 29.41 & 12 & 35.29 & 3 & 8.82 & 34 \\
\hline
\end{tabular}

The entire attributes for investment disclosure practiced by Malaysian listed companies in this study has been divided into 3 themes (i.e. Strategic Information, Financial Information and Non Financial Information. The results in Table II shows that the level of investment information disclosure varies among industry. Eighty nine companies disclosed corporate information on their websites. The construction and plantation industries disclosed the highest (20 companies each) while manufacturing industy is the lowest (14 companies). For the information on sustainability, 89 companies disclosed them on their websites. The highest number of disclosure comes were from the construction and plantation industries (20 companies each) while the lowest was from manufacturing industry (14 companies). In term of future prospect information, only 38 companies quoted theirs on websites. The plantation industry seems to be the highest to disclose (12 companies) and the lowest is trading and other industry (3 companies). In term of research and development project information via websites, it was found that only small numbers of companies (18) disclose them. The low disclosure was due to the fact that not all companies have Research and Development project. Only 45 companies disclose their corporate strategy information. Most of the information was found in the Chairman or CEO (Chief executive Officer) statement. The highest number of disclosure is construction industry (15 companies) and the lowest scored by property industry (4 companies).

In examining the financial information on the website, the study found that a total of 69 Malaysian listed companies disclosed their annual reports, and a smaller number disclosed quarterly reports (20 companies). Apart from this, 25 companies disclosed financial highlight or ratio analysis in which the highest number of disclosure is from plantation industry (8 companies) and the lowest comes from Trading and Services/Other industry (3 companies). As for the share price information, 53 companies found disclosed the information. With respect to non-financial information, the top item disclosed is social policy and value added information, which are available in 78 companies' websites. When examining into sectors, plantation industries score the highest (20 companies) while property industry was the lowest (10 companies). Other non-financial information that most companies disclosed in their website was director information (71 companies), where the companies in the construction industry reported the highest number (20 companies). The study also revealed that the least popular information disclose in this category was employees information (34 companies).

TABLE III. DISCLOSURE LEVEL OF INVESTMENTS INFORMATION OF MALAYSIAN LISTED COMPANIES VIA WEBSITE

\begin{tabular}{|c|c|c|c|c|c|c|c|}
\hline & & & & 爮 & & & $\begin{array}{c}\text { TOT } \\
A L\end{array}$ \\
\hline $\begin{array}{c}\text { TYPES OF } \\
\text { INDUSTRY }\end{array}$ & No. & $\%$ & No. & $\%$ & No. & $\%$ & No. \\
\hline Manufacturing & 10 & $10 \%$ & 4 & $4 \%$ & 6 & $7 \%$ & 20 \\
\hline Property & 6 & $7 \%$ & 10 & $11 \%$ & 4 & $4 \%$ & 20 \\
\hline Construction & 15 & $16 \%$ & 5 & $5 \%$ & 0 & $0 \%$ & 20 \\
\hline Plantation & 16 & $17 \%$ & 4 & $4 \%$ & 0 & $0 \%$ & 20 \\
\hline $\begin{array}{ll}\text { Trading and } \\
\text { Services/ } \\
\text { others }\end{array}$ & 5 & $5 \%$ & 4 & $4 \%$ & 6 & $7 \%$ & 10 \\
\hline TOTAL & 52 & $55 \%$ & 27 & $28 \%$ & 16 & $17 \%$ & \\
\hline
\end{tabular}


Table III shows the voluntary investment information disclosure practiced across industries. It is found only 52 companies (55\% of the 95 companies) made full investment disclosure on their website as Plantation and Construction sectors score the highest investment information disclosure as compared to other sectors. 27 companies (28\%) disclose at least two categories of financial information and 16 companies $(17 \%)$ reported to disclose at least 1 category of investment information in their website.

\section{B. Association between Investment Information and Explanatory Variables}

This study also intends to find the association between IVDi (Investment Disclosure Index) and selected explanatory variables. The dependent variable is represented by IVDi while the selected explanatory variables consists of company profitability (PRO), size of audit firm (AUDIT), firm efficency (EFFIC), and company size (SIZE) as seen in Table IV. The mean scores for the five strategic information items, four for financial items, and three for non financial disclosure items are $3.25,1.58$, and 1.49 , respectively. The level of overall voluntary investment information disclosed (TOTAL) in the sample range widely. The highest score is 11 , and the lowest is 0 . The mean of 3.65 and median of 5 , indicate the extent of Investment disclosure of our sample tends to be limited according to our investment information measurement scheme. Since the disclosure items are all voluntary in nature, it is not surprising that the mean score is low.

TABLE IV. DEscriptive STATISTICS

\begin{tabular}{|c|c|c|c|c|c|}
\hline & Mean & Std Dev & Min & Med & Max \\
\hline \multicolumn{6}{|c|}{ Independent variables IVDi } \\
\hline $\begin{array}{l}\text { Strategic } \\
\text { Information }\end{array}$ & 3.25 & 0.289 & 0 & 3 & 4 \\
\hline $\begin{array}{l}\text { Financial } \\
\text { Information }\end{array}$ & 1.58 & 0.132 & 0 & 2 & 4 \\
\hline $\begin{array}{l}\text { Non Financial } \\
\text { Information }\end{array}$ & 1.49 & 0.122 & 0 & 2 & 3 \\
\hline Total & 3.65 & 0.312 & 0 & 5 & 11 \\
\hline \multicolumn{6}{|c|}{ Dependent variable } \\
\hline $\begin{array}{l}\text { PRO (Company } \\
\text { Profitability) } \\
\end{array}$ & -0.09 & 0.10 & -4.47 & 0.05 & 8.79 \\
\hline $\begin{array}{l}\text { AUDIT (Size of } \\
\text { Auditing Firm) }\end{array}$ & 0.45 & 0.17 & 0 & 1 & 1 \\
\hline $\begin{array}{l}\text { EFFIC ( Firm } \\
\text { Efficiency) }\end{array}$ & 0.40 & 0.22 & 0 & 1 & 1 \\
\hline $\begin{array}{l}\text { SIZE (Company } \\
\text { size) }\end{array}$ & 6.45 & 1.24 & 2.14 & 5.89 & 11.49 \\
\hline
\end{tabular}

TABLE V. SUMMARY OF THE REGRESSION RESULTS

\begin{tabular}{l|c|c|c|}
\hline & Coefficients & T & P values \\
\hline (Constant) & -0.910 & -3.275 & 0.002 \\
\hline PRO & 0.000 & 1.279 & 0.204 \\
\hline AUDIT & 0.000 & -0.233 & 0.816 \\
\hline EFFIC & 0.042 & 0.671 & 0.181 \\
\hline SIZE & 0.076 & 4.112 & $0.000^{* *}$ \\
\hline
\end{tabular}

Table $\mathrm{V}$ reveals the summary of the regression results. The highest Pearsons correlation coefficient among the independent variables found is 0.72 . This implies that there is no severe multicollinearity problem in the regression procedure. As cited by Abdullah and Ku-Ismail (2008), a model is said to suffer a multicollinearity problem only when the coefficient is equal to or greater than 0.9. Positive relationship is found at one percent between investment information disclose and SIZE. This provides early signal that larger firms tend to provide better investment information. The adjusted $\mathrm{R}^{2}$ and $\mathrm{F}$ values of 0.112 and 5.941, respectively, imply that the model is significant. The model can explain 11.2 percent of the variation in the extent of IVDi. The results indicate that all the variables have coefficients of the expected sign. However, the association is not statistically significant except for SIZE. This implies that larger firm tends to provide more investment information on their website. Previous studies (see Martson 2003; Khadaroo 2005 and Watts and Zimmerman 1986) also found similar results signaling/indicating that larger companies have more relevant information to be disclosed. Furthermore, larger companies may have better resources or infrastructure that can facilitate the implementation of internet business reporting.

\section{CONCLUSION}

This study attempt to examine the voluntary disclosure of investment information in Malaysian companies website. With respect to the extent of investment information, this study found that Malaysian companies attentive in disseminating their financial and non-financial information in the web sites as compared to the previous researches' findings (e.g. Abdul Hamid, 2005, and Khadaroo, 2005). However, there are five companies do not have their website during the period of study. None of the companies use XBRL reporting format. In terms of multimedia application, only 40 companies adopt flash animation, 6 companies use video and 5 companies use audio to disseminate information via websites. Less than 50 companies disclose information pertinent to future prospects, research and development, quarterly report, financial highlight and information related to the employees. Only 52 companies reported to be full disclosure whereby they disclosed all the three major groups of investment information. The overall level of voluntary investments information in the sample range widely. The highest number of disclosure is 11 , and the lowest is 0 . The mean (median) is 3.65 (5), which indicates that the extent of investment information disclosure of our sample tend to be limited, according to our investment information measurement scheme. Since the disclosure items are all voluntary in nature, it is not surprising that the mean score is low. The result of the study shows that the highest correlation coefficient among the independent variables is 0.72 . This implies that there is no severe multicollinearity problem in the regression procedure. The adjusted $\mathrm{R}^{2}$ and $\mathrm{F}$ values of 0.112 and 5.941, respectively, imply that the model is significant. Ordinary least square analysis of firm's profitability, firm's issuance of new shares, firm's auditor, 
firm's efficiency and firm's size, indicate only firm's size is significant in determining the level of web based reporting.

It is observed that little effort taken by some Malaysian companies in producing investment information to investor community through their websites. Investor may not gain much information because effective comparison could not be made due to the variation of information and lack of reporting among firms. Regulators should encourage companies to disclose more investment information in the website and at the same time thinking of the way to standardize information through electronics reporting. Due to the emerging of technology advancement nowadays, this would provide easiness and confidence to the investor in obtaining information to the companies' performance and making investment decision. Since this study only addressed the investment information at the firm level and highlight how the companies disclosed such information, it is recommended for further study to focus on how useful the investment information would be to the investors. It is also can be addressed by comparing firms across countries.

\section{REFERENCES}

[1] Abdul Hamid F Z (2005) ' Malaysian Companies' Use of the Internet for Investor Relations', Corporate Goverannce.

[2] Abdullah A and Ku Ismail (2008). Disclosure of Voluntary Ratios by Malaysian Listed Companies. Journal of Financial Reporting and Accounting, Vol 6, pp.1-20

[3] Ahmed, K. and Courtis, J.K. (1999). Associations between corporate characteristics and disclosure level in annual reports: a meta-analysis. British Accounting Review, vol 31, pp. 35-61.

[4] Ahmed, K. and Nicholls, D. (1994). The impact of non-financial company characteristics on mandatory disclosure compliance in developing countries: the case of Bangladesh. The International Journal of Accounting, Vol. 29(1), pp. 62

[5] Ashbaugh H, Johnstone K M, Warfield T D, (1999). 'Coroprate Reporting on the Internet', Accountancy Horizons, Sarasota: Sept 1999. Vol. 13, Iss. 3

[6] Beattie, V. and Jones, M.J. (1992). The use and abuse of graphs in annual reports: theoretical framework and empirical study. Accounting \& Business Research, Vol.22 (88), pp. 291-303.

[7] Belkaoui, A. and Khal, A. (1978).Corporate Financial Disclosure in Canada, CCGAA Research Monograph.

[8] Bonson Ponte, Ecobar Rodriguez and Sanches Barrios, (2003). 'Corporate Digital Reporting in Europe. A Survey on Eurostoxx50 Companies', Paper presented at the 3rd European Conference on Accounting Information Systems. 27-28 March 2000.Munich.

[9] Botosan, C. (1997), 'Disclosure level and the Cost of Equity Capital', The Accounting Review, Vol. 72 No.3, pp.323-49.

[10] Brennan, N., Kelly, S.(2000), "Use of the internet by Irish Co.s for Investor Relations Purposes", Accountancy Ireland, Aug., pp.23-5.

[11] Buzby, S.L. (1975), "Company size, listed versus unlisted stocks, and the extent of financial disclosure", Journal of Accounting Research, Vol. 13 No.1, pp.16-37.

[12] Connor O'Kelly(2000). 'Business reporting on the Internet: Reporting gets personal', AccountancyIreland, Dublin: Aug 2000. Vol. 32, Iss. 4

[13] Deller, D., Stubenrath, M., Weber, C. (1999), "A survey on the use of the internet for the investor relations in the USA, UK and Germany", The European Accounting Review, Vol. 8 No.2, pp.351-64.

[14] Firth, M., (1979).The impact of size, stock market listing and auditors on voluntary disclosure in corporate annual reports. Accounting and Business research, Autumn, pp.273-280
[15] Global Reporting Initiative(2000).'SustainabilityReporting Guidelines on Economic, Environmental and Social Reporting' Boston.

[16] Gowthorpe C. and Flynn G. (1997). 'Reporting on the Web: The state of the art', Accountancy, London: Aug 1997, Vol. 120, Iss. 1248

[17] Green, G.; Spaul, B. (1997). 'Digital Accountability', Accountancy; May; pp. 49-50

[18] Hedlin,P.(1999), "The internet as a vehicle for investor relations: the Swedish case", The European Accounting Review,Vol.8,No.2, pp.37381.

[19] Hussey, R., Gulliford, J.R. and Lymer, A. (1998), Corporate Communications: Financial Reporting on the Internet, Deloitte \& Touche, London

[20] Inchausti , B.G.(1997). The Influence of Company Characteristic and Accounting Regulation on Information Disclosed by Spanish Firms. The European Accounting Review, Vol. 6(1), pp. 45-48.

[21] Ismail T.H. (2002) “An Empirical Investigation Of Factors Influencing Voluntary Disclosure Of Financial Information On The Internet In The GCC Countries", Working Paper Series:

[22] Khadaroo I (2005), "Corporate reporting on the internet: some implications for the auditing profession", Managerial Auditing Journal, Vol.20, No. 6,

[23] Lev, B. (1992), "Information disclosure strategy", California Management Review, summer, pp.9-32.

[24] Louwers, Timothy J, Pasewark, William R, Typpo and Eric W. (1997). 'The Internet: Changing the way corporations tell their story', The CPA Journal, New York: Nov 1996. Vol. 66, Iss. 11

[25] Lymer, A.; Tallberg, A. (1997): "Corporate Reporting and the Internet a Survey and Commentary on the Use of the WWW in Corporate Reporting in the UK and Finland". Paper presented at the 20th Annual Congress of the European Accounting Association, Graz, Austria.

[26] Marston, C. (2003), "Financial reporting on the internet by leading Japanese companies", Corporate Communications: An International Journal, Vol. 8 No. 1, pp. 23-34.

[27] Marston, C. and Leow, C.Y. (1998), "Financial reporting on the internet by leading UK companies", paper presented at EAA'98, Antwerp.

[28] Maines L, Bartov E., M Fairfield P, Hirst D E, . (2002) 'Recommendations on Disclosure of Non Financial Performance Measure', Accountancy Horizons, Sarasota: Dec 2002. Vol. 16, Iss. 4

[29] Naser, K. (1998). Comprehensiveness of disclosure of non-financial companies listed on the Amman Financial Market. International Journal of Commerce and Management, Vol.8 (1), pp. 88-119.

[30] Niamh Brennan. Denis Hourigan. (1998). 'Corporate Reporting on the Internet by Irish companies'. Accountancy Ireland Dublin. Dec 1998. Vol. 30, Iss. 6; pg. 18

[31] Raffournier,B.(1995).The determinants of Voluntary Financial Disclosure by Swiss listed Cos. The European Accounting Review, Vol. 4(2), pp. 261-80.

[32] Roscoe, J.T. (1975).Fundamental Statistics for the Behavioural Science. New York: Holt, Rinehart and Winston.

[33] Shelly, B. G. and Vermaat, E. M. (2009). Discovering Computer2009. USA. Course Technology, Cengage Learning.

[34] Singhvi,S., Desai, H.B.(1971), "An empirical analysis of the quality of corporate financial disclosure", Accounting Review, No.1, pp.129.

[35] The Association of Chatered Certified Accountants (ACCA) (2005). 'Sustainability Reporting Guidelines for Malaysian Companies'. Kuala Lumpur.

[36] The Association of Cahtererd Certified Accountants (ACCA) (2001). 'Environmental, Social and Sustainability Reporting on the World Wide Web: A Guide to Best Practice'. Kuala Lumpur.

[37] Wallace, R.S.O., Naser, K. and Mora, A. (1994). The relationship between the comprehensiveness of corporate annual reports and firm characteristics in Spain. Accounting and Business Research, Vol. 25(97), pp. 41-53. 
Please cite this paper as: Abdullah, A., Mohd Isa, R., \& Mat Isa, N. (2011, 5-6 Dec. 2011). Investment information via website by Malaysian listed companies. Paper presented at the Humanities, Science and Engineering (CHUSER), 2011 IEEE Colloquium on.

[38] Wallace, R.S.O. and Naser, K. (1995). Firm-specific determinants of the comprehensiveness of mandatory disclosure in corporate annual reports of firms listed on the Stock Exchange of Hong Kong. Journal of Accounting and Business Research, Vol. 18(72), pp.352-362.

[39] Watts, R. and Zimmerman, J. (1986). Towards a Positive Theory of the determination of Accounting Standard,. The Accounting Review, Vol.53 pp. 112-34 